Hao $\mathrm{CHEN}^{1}$

\title{
TRAFFIC AND TILLAGE EFFECTS ON SOIL WATER CONSERVATION AND WINTER WHEAT YIELD IN THE LOESS PLATEAU, CHINA
}

\author{
WPEYW SPOSOBU UPRAWY ROLI NA OCHRONE WODY GLEBOWEJ \\ I PLONY PSZENICY OZIMEJ NA WYŻYNIE LESSOWEJ, CHINY
}

\begin{abstract}
In semi-humid Loess Plateau of northern China, water is the limiting factor for rain-fed crop yields. In this region, long-term traditional ploughing with straw removal has resulted in poor soil structure, water conservation and crop yield. Controlled traffic, combined with no-till and straw cover has been proposed to improve soil water conservation and crop yield. From 1999 to 2007, a field experiment on winter wheat was conducted in the dryland area of Loess Plateau of northern China, to investigate the effects of traffic and tillage on soil water conservation and crop yield. The field experiment was conducted using two controlled traffic treatments, no tillage with residue cover and no compaction (NTCN), shallow tillage with residue cover and no compaction (STCN) and one conventional tillage treatment (CK). Results showed that controlled traffic system reduced soil compaction in the top soil layer, increased soil water infiltration. The benefit on soil water infiltration translated into more soil conservation (16.1\%) in 0-100 cm soil layer in fellow period, and achieved higher soil water availability at planting $(16.5 \%)$, with less yearly variation. Consequently, controlled traffic system increased wheat yield by $12.6 \%$ and improved water use efficiency by $5.2 \%$, both with less yearly variation, compared with conventional tillage. Within controlled traffic treatments, no tillage treatment NTCN showed better overall performance. In conclusion, controlled traffic combined with no-tillage and straw cover has higher performance on conserving water, improving yield and water use efficiency. It is a valuable system for soil and water conservation for the sustainable development of agriculture in dryland China.
\end{abstract}

Keywords: controlled traffic, winter wheat, water conservation, wheat yield, Loess Plateau

\section{Introduction}

In semiarid Loess Plateau of northern China, dry land farming with winter wheat, accounting for about $80 \%$ of total cultivated lands, is the most common farming mode. Due to the inconsistent between growing seasons (from mid-September to next June) and rainy seasons (July to September, with more than $60 \%$ of rainfall), soil water conservation is critical to winter wheat production. Winter wheat yield and water use efficiency depend strongly on soil available water due to less rainfall and uneven rainfall distribution [1]. The importance of storing soil water for increasing wheat yield and water use efficiency has

\footnotetext{
${ }^{1}$ College of Automotive Engineering, Shanghai University of Engineering Science, Shanghai, 201620, China, phone +86 13585901312, fax +86 2167791152, email: pschenhao@163.com
} 
been supported by many dryland studies including those in Loess Plateau of China by Shangguan et al [2] and Wang et al [3] and in the dryland area of Australia by Tullberg et al [4]. Traditional farming resulted in serious loss of precipitation collected during the raining season [5], poor soil physical and chemical properties [6] and low available water because of high potential evaporation, bare fallowing and over-tillage, therefore reduced crop yield and water use efficiency [7]. Shangguan et al [2] reported that fallow rainfall storage efficiency was only 35 to $40 \%$ under traditional tillage in Loess Plateau. Wang et al [8] showed that crop yield and water use efficiency tended to be lower in traditional tillage in Loess Plateau, especially in the years of low rainfall, due to damaged soil structure and decreased soil moisture. Therefore, ameliorating soil structure, improving soil available water and water use efficiency, and increasing crop yield are extremely necessary and will be significant to the sustainable development of dry land agriculture.

Controlled traffic system, combining with minimum or zero tillage and straw mulch, is considered as an effective way to increase crop yield and water use efficiency due to improved soil structure and increased soil water storage capacity, especially in arid region [9-12]. Radford et al [13] reported that controlled traffic provides a range of advantages in terms of infiltration, plant available water capacity and crop productivity. Li et al [14] observed that controlled traffic zero tillage increased $12.0 \%$ rainfall infiltration, $11.5 \%$ plant available water capacity in $0-500 \mathrm{~cm}$ zone and $9.4 \%$ mean yield, compared with wheeled stubble mulched treatment.

In Loess Plateau of China, a series of research has been conducted to investigate the effect of controlled traffic system. Wang et al [15] reported initial results of experimental trials for a single maize cropping system on the Central Loess Plateau. In their tests, runoff from controlled traffic was $20 \%$ lower than from conventional tillage plots, and soil erosion declined by $16 \%$. Chen et al [16] reported that without decreasing crop yield, controlled traffic system improved soil structure and induced higher water infiltration. Controlled traffic with conservation tillage increased accumulative infiltration by $25.8 \%$, compared with non-controlled traffic treatments. Based on continuous experiments, Wang et al [3] reported significantly increase of soil water content in the $0-150 \mathrm{~cm}$ soil profile at sowing, which result in $6.9 \%$ increase in winter wheat yield, and less yearly variation. Bai et al [17] reported $67.4 \%$ greater final water infiltration rates and $14.9 \%$ higher water content in $130 \mathrm{~cm}$ soil layer for controlled traffic system, compared with traditional farming system. However, in semiarid Loess Plateau of northern China, there is no systematic research on the long-term effects of controlled traffic on soil water conservation characteristics. It is unclear how does long-term controlled traffic practice positively change soil water characteristics, and its relation to crop yield. A long-term field experiment was conducted with winter wheat to investigate the effects of controlled traffic on soil water conservation characteristics and crop yield.

\section{Material and methods}

\section{Sites}

The experiment plot was set up in annual one crop region of Chenghuang village $\left(37^{\circ} 32^{\prime}-38^{\circ} 6^{\prime} \mathrm{N}, 112^{\circ} 4^{\prime}-113^{\circ} 26^{\prime} \mathrm{E}\right)$, Linfen city, Shanxi province. The altitude is range from 360 to $500 \mathrm{~m}$. Average annual temperature is $10-12^{\circ} \mathrm{C}$ with 130 frost-free days. The site has a semiarid, warm-temperate climate and frequent drought, with average annual rainfall of 
$380-553 \mathrm{~mm}$, falling mainly from July to September. The annual evaporation is $1800 \mathrm{~mm}$. The fallow period is from the middle 10 days of June to the middle 10 days of September. The erosion index is less than 400 ton $\mathrm{km}^{-2}$ year $^{-1}$.

The soil in the experimental plots is a silt loam (sand, 18.8\%; silt, $77.5 \%$; clay, 3.7\%) derived from loess parent material. The soils are low in organic matter content $(0.9 \%$; 0 to $400 \mathrm{~mm}$ depth) and slightly alkaline ( $\mathrm{pH} \mathrm{7.9).} \mathrm{The} \mathrm{soils} \mathrm{of} \mathrm{Loess} \mathrm{Plateau} \mathrm{are} \mathrm{generally}$ described as porous and homogenous to considerable depth with limited variance across fields [18].

\section{Experiment design}

The effects of traffic management and tillage on winter wheat were studied from 1998 to 2007. There were 3 treatments with 5 replications: no tillage with straw cover and no compaction (NTCN), shallow tillage with straw cover and no compaction (STCN) and conventional tillage (CK).

NTCN: a controlled traffic treatment, no tillage, straw cover and none compaction in crop zone. In this treatment, $30 \mathrm{~cm}$ high wheat stubble was left at harvest, and all wheat straw was returned to the plots after being threshed. In the fallow period, there was no tillage - weeds controlled by herbicides only. Wheat was sown with a no-till planter in September.

STCN: another controlled traffic treatment, shallow tillage, straw cover and none compaction in crop zone. In this treatment, $30 \mathrm{~cm}$ high wheat stubble was left at harvest, and all wheat straw was returned to the plots after being threshed. In the fallow period, there was no tillage. Shallow tillage was done before sowing with a two-shovel sweep at a depth of $5 \sim 8 \mathrm{~cm}$, and then wheat was sown in September using the same sowing machine used for NTCN.

CK: the conventional tillage treatment. In this treatment, random wheel traffic was used. 5-6 cm high wheat stubble was left at harvest, but the wheat straw was not returned to the plots. The soil was ploughed to a depth of $20 \mathrm{~cm}$ after the first summer rain, and mechanical weed control was used in the fallow period. Before sowing, the plot was plowed again to $20 \mathrm{~cm}$ by moldboard plough, then harrowed and dragged before wheat was sown with a conventional planter in September.

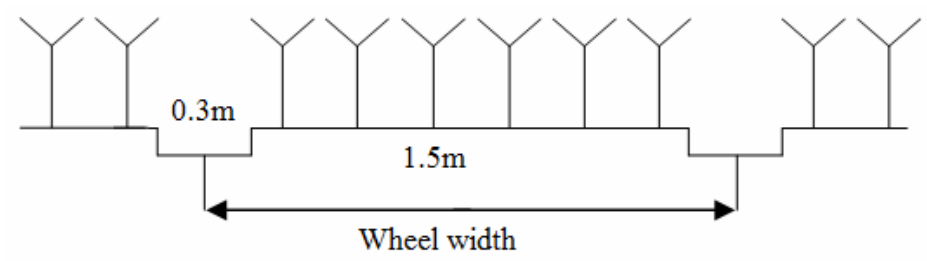

Fig. 1. Traffic lanes and crop rows layout for winter wheat

The layout of crop rows and permanent traffic lanes were designed as presented in Figure 1 according to the characteristics of local tractors and planters. The width of each traffic lane is $30 \mathrm{~cm}$, occupying $20 \%$ of land area, and six rows of winter wheat with $20 \mathrm{~cm}$ of row space were planted between two neighbor wheel tracks. Each plot is $4.5 \mathrm{~m}$ wide and $30 \mathrm{~m}$ long. 
Before the treatments were applied, the experimental area was ploughed $(30 \mathrm{~cm} \mathrm{depth})$ to provide uniform soil conditions. To make the treatments comparable, the same rates of fertilizer and seed were used each year. Every season, fertilizer was applied at the rate of $150 \mathrm{~kg} \mathrm{~N} \mathrm{ha}^{-1}, 140 \mathrm{~kg} \mathrm{P} \mathrm{ha}^{-1}$ and $62 \mathrm{~kg} \mathrm{~K} \mathrm{ha}^{-1}$ and the seeding rate was $225 \mathrm{~kg} \mathrm{ha}^{-1}$. Wheat was sown in the last ten days of September and harvested in the first ten days of June.

\section{Measurements}

\section{Soil bulk density and water content}

In each plot, six random soil samples were taken using a 54-mm-diameter steel core sampling tube, manually driven into a $100-\mathrm{cm}$ depth. The soil cores were split into ten sections: $0-0.1 \mathrm{~m}, 0.1-0.2 \mathrm{~m}, 0.2-0.3 \mathrm{~m}, 0.3-0.4 \mathrm{~m}, 0.4-0.5 \mathrm{~m}, 0.5-0.6 \mathrm{~m}, 0.6-0.7 \mathrm{~m}$, $0.7-0.8 \mathrm{~m}, 0.8-0.9 \mathrm{~m}$ and $0.9-1.0 \mathrm{~m}$. These samples were then weighed when wet, dried at $105^{\circ} \mathrm{C}$ for $48 \mathrm{~h}$, and weighed again to determine bulk density.

Soil water content was measured by the gravimetric method by taking soil cores at the sowing and harvest date of each growing season. Soil cores were divided into $10 \mathrm{~cm}$ increment from soil surface to $100 \mathrm{~cm}$ depth. The mean soil moisture content for all treatments was computed as soil moisture level of each depth.

\section{Fallow water storage}

Fallow precipitation storage efficiency (PSE) was calculated as the difference in the soil water content within the $100 \mathrm{~cm}$ profile between the beginning and end of the summer fallow period, using the following equation:

$$
P S E=\frac{S W P-S W H}{P_{F}} \times 100 \%
$$

where $S W P$ is the amount of soil water storage at planting, $S W H$ is the amount of soil water storage after harvesting, $P_{F}$ is the total precipitation during fallow period.

\section{Infiltration}

The infiltration of water into the soil was determined by the double ring infiltrometer method, with a $30-\mathrm{cm}$ inner diameter and $60-\mathrm{cm}$ outer diameter cylinder. The infiltrometer was inserted for $10 \mathrm{~cm}$ into the soil on the experimental field (five replicates for each treatment). A constant water head of $20 \mathrm{~mm}$ was maintained in both rings, and the rate of infiltration was measured using discharge from a calibrated Mariotte bottle.

\section{Yield and WUE}

Wheat grain yields was determined at $12 \%$ moisture content by manually harvesting $3 \mathrm{~m}$ length of rows taken randomly in each plot, with 4 replications. Seasonal evapotranspiration $(E T)$ for individual plots was determined for each growing season using the soil water balance equation:

$$
E T=P+I-\Delta W
$$

where $E T$ is the evapotranspiration of the growing wheat, $P$ is the total growing seasonal rainfall, $I$ is the irrigation, $\Delta W$ is the soil water change (final minus initial) from planting to harvesting, which was calculated by subtracting the total soil water content at $100 \mathrm{~cm}$ depth 
of soil profile. In this experiment, there is no irrigation, so $I$ in Eq. (2) was zero for all plots. Total Water use efficiency (WUE) was calculated as the winter wheat yield $\left[\mathrm{t} \mathrm{ha}^{-1}\right]$ divided by the growing season evapotranspiration $(E T)$.

\section{Statistical analysis}

Mean values and standard deviations (S.D.) were calculated. All data were subjected to analysis of variance using ANOVA to assess the effects of traffic management and tillage on the measured variables. When ANOVA indicated a significant F-value, multiple comparisons of annual mean values were performed by the least significant difference method (LSD) [19]. In all analyses, a probability of error smaller than 5\% $(P<0.05)$ was considered statistically significant. The SPSS analytical software package (13.0) was used for all the statistical analyses.

\section{Results and discussion}

\section{Soil bulk density}

Controlled traffic treatments showed lower soil bulk density in upper soil layer. Significantly lower value was observed in 10-20 cm layer in controlled traffic treatments $(P<0.05)$ (Table 1). This was due to the avoiding of soil compaction in crop zone by permanently separating crop areas and traffic lanes in controlled traffic system. Random traffic from field operations and annual ploughing in traditional tillage leads to soil compaction and the formation of a plough pan in the lower soil profile [20].

In 0-10 cm layer, expected significant difference was not observed between controlled traffic treatments and conventional tillage treatment, which was probably due to the effect of root growth in top soil layer at sampling time. STCN showed significantly lower bulk density than NTCN, due to effect of the shallow tillage. Consistent with bulk density, similar tendency was observed in total porosity.

Bulk density and total porosity of the three treatments in $0-40 \mathrm{~cm}$ layer

\begin{tabular}{|c|c|c|c|c|c|c|c|c|}
\hline & \multicolumn{4}{|c|}{ Bulk density $\left[\mathbf{g} / \mathbf{c m}^{3}\right]$} & \multicolumn{4}{c|}{ Total porosity $\left[\mathbf{c m}^{\mathbf{3}} / \mathbf{1 0 0} \mathbf{~ c m}^{\mathbf{3}}\right]$} \\
\cline { 2 - 9 } & $\mathbf{0 - 1 0} \mathbf{~ c m}$ & $\mathbf{1 0 - 2 0} \mathbf{~ c m}$ & $\mathbf{2 0 - 3 0} \mathbf{~ c m}$ & $\mathbf{3 0 - 4 0} \mathbf{~ c m}$ & $\mathbf{0 - 1 0} \mathbf{~ c m}$ & $\mathbf{1 0 - 2 0} \mathbf{~ c m}$ & $\mathbf{2 0 - 3 0} \mathbf{~ c m}$ & $\mathbf{3 0 - 4 0} \mathbf{~ c m}$ \\
\hline NTCN & $1.37^{\mathrm{a}}$ & $1.31^{\mathrm{a}}$ & $1.36^{\mathrm{a}}$ & $1.44^{\mathrm{a}}$ & $48.25^{\mathrm{a}}$ & $50.88^{\mathrm{a}}$ & $49.20^{\mathrm{a}}$ & $46.06^{\mathrm{a}}$ \\
\hline STCN & $1.20^{\mathrm{b}}$ & $1.36^{\mathrm{a}}$ & $1.41^{\mathrm{a}}$ & $1.44^{\mathrm{a}}$ & $54.67^{\mathrm{b}}$ & $49.00^{\mathrm{a}}$ & $47.33^{\mathrm{a}}$ & $46.06^{\mathrm{a}}$ \\
\hline CK & $1.27^{\mathrm{ab}}$ & $1.54^{\mathrm{b}}$ & $1.41^{\mathrm{a}}$ & $1.45^{\mathrm{a}}$ & $52.03^{\mathrm{ab}}$ & $42.26^{\mathrm{b}}$ & $47.33^{\mathrm{a}}$ & $45.68^{\mathrm{a}}$ \\
\hline
\end{tabular}

Means within a row in the same year followed by the same letters are not significantly different at $P<0.05$.

\section{Soil water infiltration}

Figure 2 showed the soil water infiltration character for different treatments in 2007. Due to the effect of wheel traffic and tillage on soil structure, infiltration showed different feature among treatments.

Wheel traffic showed significant effect on soil water infiltration. As soil compaction was avoided in NTCN and STCN, lower soil bulk density and higher soil porosity result in higher value in infiltration rate and infiltration accumulation. NTCN reached steady infiltration $(0.233 \mathrm{~cm} / \mathrm{min})$ in 86 minutes, STCN reached steady infiltration $(0.391 \mathrm{~cm} / \mathrm{min})$ in 53 minutes, and CK reached steady infiltration $(0.138 \mathrm{~cm} / \mathrm{min})$ in 35 minutes. Averagely, 
controlled traffic treatment was $126 \%$ higher than CK, and with significant difference between STCN and CK $(P<0.05)$. Consequently, the accumulation infiltration and infiltration depth were higher in controlled traffic treatments. After 140 minutes of infiltration test, the accumulation infiltration for NTCN, STCN and CK were 44.2, 60.7 and $35.6 \mathrm{~cm}$, respectively. Significant difference was observed between STCN and CK $(P<0.05)$. Compared with $\mathrm{CK}, \mathrm{NTCN}$ and STCN increased accumulation infiltration 24 and $70 \%$. The infiltration depth increased 64 and $86 \%$ in NTCN and STCN, compared with CK. This can be explained by improved water retention capacity caused by greater capillary pores in controlled traffic plots [21]. These results on water infiltration were consistent with a 5-year controlled traffic experiment conducted in southeastern Queensland, Australia [22], which demonstrated that the steady infiltration rate in controlled traffic plots was four to five times higher than that in non-controlled traffic plots.
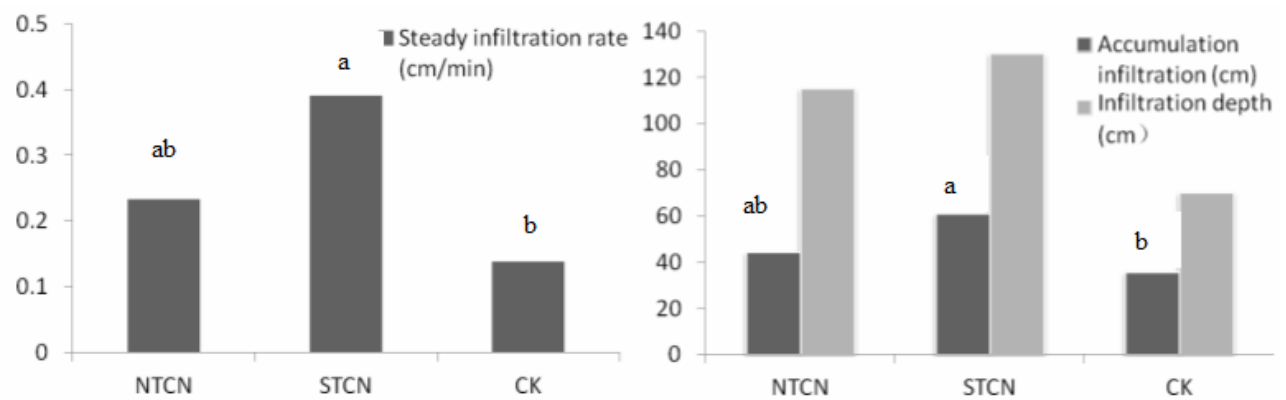

Fig. 2. Soil water infiltration character for different treatments. Left: steady infiltration [cm/min], Right: accumulation infiltration $[\mathrm{cm}]$ in 140 mins

As tilled soil has advantage in infiltration, STCN showed benefits on water infiltration, compared with NTCN, but without significant difference $(P<0.05)$.

\section{Soil water storage during the fallow period}

The wheel traffic and tillage differentially affected the amount of soil water storage year to year during the fallow period depending on fallow management and environmental conditions, shown as Table 2. As soil water infiltration capacity increased in controlled traffic system, soil water storage capability was increased consequently, averagely $16.1 \%$ higher.

With the exception of 2000 and 2003, controlled treatments (NTCN and STCN) showed significantly higher capacity in fellow rainfall storage at $P<0.05$ level, compared with CK. Compared with CK, NTCN and STCN increased fellow water storage 17.1 and $15.1 \%$, respectively. Especially in 2002 and 2004, soil water storage for NTCN and STCN significantly increased about $20 \mathrm{~mm}$ compared with $\mathrm{CK}$, despite the lower-than-average fallow period precipitation of 43.8 and $65.2 \mathrm{~mm}$ in 2002 and 2004, respectively.

$P S E$ varied highly during experimental period because of different annual precipitation. Consistent with FWS, controlled traffic treatments showed higher value in PSE. Mean PSE for controlled traffic was $16.5 \%$ significantly higher than for CK during the study period. In six years, PSE for controlled traffic was significantly higher than conventional tillage 
$(P<0.05)$. One reason was the straw mulch under controlled traffic management, which prevented soil water evaporation and improved rainfall infiltration, therefore increased PSE. Another possibility was the reduction of root zone compaction, which ameliorated soil aggregation stability, soil capillary porosity and soil-water relationships, thus increased soil available water.

Table 2

Fallow rainfall storage efficiency for different treatments from 1999 to 2006

\begin{tabular}{|c|c|c|c|c|c|c|c|c|c|c|}
\hline & & 1999 & 2000 & 2001 & 2002 & 2003 & 2004 & 2005 & 2006 & Mean \\
\hline \multirow{3}{*}{$\begin{array}{l}F W S \\
{[\mathrm{~mm}]}\end{array}$} & NTCN & $112.5^{\mathrm{a}}$ & $65.4^{\mathrm{a}}$ & $164.8^{\mathrm{a}}$ & $83.3^{\mathrm{a}}$ & $188.2^{\mathrm{a}}$ & $72.9^{\mathrm{a}}$ & $123.3^{\mathrm{a}}$ & $134.0^{\mathrm{a}}$ & 118.1 \\
\hline & STCN & $121.9^{\mathrm{a}}$ & $62.1^{\mathrm{a}}$ & $161.5^{\mathrm{ab}}$ & $89.7^{\mathrm{a}}$ & $192.2^{\mathrm{a}}$ & $73.9^{\mathrm{a}}$ & $113.1^{\mathrm{ab}}$ & $114.0^{\mathrm{b}}$ & 116.1 \\
\hline & $\mathrm{CK}$ & $97.3^{\mathrm{b}}$ & $66.0^{\mathrm{a}}$ & $152.6^{\mathrm{b}}$ & $61.3^{b}$ & $177.1^{\mathrm{a}}$ & $54.5^{\mathrm{b}}$ & $104.7^{b}$ & $92.5^{\mathrm{c}}$ & 100.8 \\
\hline \multirow{3}{*}{$P S E[\%]$} & NTCN & $44.0^{\mathrm{a}}$ & $24.4^{\mathrm{a}}$ & $58.8^{\mathrm{a}}$ & $36.4^{\mathrm{a}}$ & $47.1^{\mathrm{a}}$ & $31.8^{\mathrm{a}}$ & $46.1^{\mathrm{a}}$ & $32.3^{\mathrm{a}}$ & 40.1 \\
\hline & STCN & $47.6^{\mathrm{a}}$ & $23.1^{\mathrm{a}}$ & $57.6^{\mathrm{ab}}$ & $39.2^{\mathrm{a}}$ & $48.1^{\mathrm{a}}$ & $35.7^{\mathrm{a}}$ & $40.4^{\mathrm{ab}}$ & $27.5^{\mathrm{ab}}$ & 39.9 \\
\hline & CK & $38.6^{\mathrm{b}}$ & $24.6^{\mathrm{a}}$ & $54.4^{\mathrm{b}}$ & $26.8^{b}$ & $44.4^{\mathrm{a}}$ & $26.3^{b}$ & $37.1^{\mathrm{b}}$ & $22.4^{\mathrm{b}}$ & 34.3 \\
\hline
\end{tabular}

1. Means within a row in the same year followed by the same letters are not significantly different at $P<0.05$.

2. FWS represents fellow water storage amount, PSE represents precipitation storage efficiency.

Between two controlled traffic treatments, STCN showed lower value in fellow water storage than NTCN. The benefits of shallow tillage on infiltration did not result into higher soil water conservation. Soil disturbance in shallow tillage result in less ground cover, a greater surface area for evaporation, higher soil temperature, and possibly a greater gas permeability of the shallow tilled layer, thus increases soil moisture loss.

\section{Soil water available at wheat planting}

With the positive effect on fellow water storage in controlled traffic system, more soil water was conserved, thus higher value of soil water available $(0-100 \mathrm{~cm}$ soil layer) at wheat planting was observed, shown in Table 3. Controlled traffic treatments increased soil water available at planting throughout the experiment period, with significant difference in seven years $(P<0.05)$. Mean soil water available from 1999 to 2007 for controlled traffic treatments was $16.5 \%$ significantly higher than conventional tillage at planting time.

Table 3

Soil water available [mm] at wheat planting time for 1999-2007 at depth of 0-100 cm

\begin{tabular}{|c|c|c|c|c|c|c|c|c|c|c|}
\hline & $\mathbf{1 9 9 9}$ & $\mathbf{2 0 0 0}$ & $\mathbf{2 0 0 1}$ & $\mathbf{2 0 0 2}$ & $\mathbf{2 0 0 3}$ & $\mathbf{2 0 0 4}$ & $\mathbf{2 0 0 5}$ & $\mathbf{2 0 0 6}$ & $\mathbf{2 0 0 7}$ & Mean \\
\hline NTCN & $233.3^{\mathrm{a}}$ & $201.8^{\mathrm{a}}$ & $254.5^{\mathrm{a}}$ & $235.7^{\mathrm{a}}$ & $283.3^{\mathrm{a}}$ & $230.6^{\mathrm{a}}$ & $249.6^{\mathrm{a}}$ & $288.7^{\mathrm{a}}$ & $252.2^{\mathrm{a}}$ & 247.7 \\
\hline STCN & $236.6^{\mathrm{a}}$ & $199.5^{\mathrm{a}}$ & $256.9^{\mathrm{a}}$ & $243.9^{\mathrm{a}}$ & $282.6^{\mathrm{a}}$ & $231.5^{\mathrm{a}}$ & $251.2^{\mathrm{a}}$ & $259.0^{\mathrm{ab}}$ & $229.0^{\mathrm{b}}$ & 243.4 \\
\hline CK & $158.4^{\mathrm{b}}$ & $198^{\mathrm{a}}$ & $246.1^{\mathrm{a}}$ & $198.8^{\mathrm{b}}$ & $262.7^{\mathrm{b}}$ & $207.1^{\mathrm{b}}$ & $240.4^{\mathrm{b}}$ & $242.3^{\mathrm{b}}$ & $209.3^{\mathrm{c}}$ & 218.1 \\
\hline
\end{tabular}

Means within a row in the same year followed by the same letters are not significantly different at $P<0.05$.

Less deviation was demonstrated that soil available water in controlled traffic treatments, which means more stable water conservation capacity compared with conventional tillage. The reason can be explained by higher rainfall storage capacity in controlled traffic treatments during fallow seasons, especially in the dry fallow seasons (Table 2), therefore diminished the effects of yearly variation of precipitation and provided more stable soil water available for crop. 
The experimental data indicated that traffic management and tillage significantly affected soil water storage at planting time. Conventional tillage had exposed moist soil channels, thus increased fluxes of water, decreased soil storage capacity [23, 24]. While through improving soil physical structure and increasing water infiltration, controlled traffic systems, both NTCN and STCN treatments, conserved more water [25], and reduce yearly variation to keep more stable water supply for crop production.

\section{Yield}

Soil water is the vital factor for winter wheat production in Loess Plateau in China. The higher capacity of soil water conservation eventually translated into higher crop yield, shown in Table 4.

Winter wheat yield from 1999 to 2007 [ton/hm²]

Table 4

\begin{tabular}{|c|c|c|c|c|c|c|c|c|c|c|}
\hline & $\mathbf{1 9 9 9}$ & $\mathbf{2 0 0 0}$ & $\mathbf{2 0 0 1}$ & $\mathbf{2 0 0 2}$ & $\mathbf{2 0 0 3}$ & $\mathbf{2 0 0 4}$ & $\mathbf{2 0 0 5}$ & $\mathbf{2 0 0 6}$ & $\mathbf{2 0 0 7}$ & Mean \\
\hline NTCN & $3.27^{\mathrm{a}}$ & $2.48^{\mathrm{a}}$ & $3.08^{\mathrm{a}}$ & $3.68^{\mathrm{a}}$ & $3.51^{\mathrm{a}}$ & $4.01^{\mathrm{a}}$ & $2.71^{\mathrm{a}}$ & $4.43^{\mathrm{a}}$ & $4.76^{\mathrm{a}}$ & 3.55 \\
\hline STCN & $3.45^{\mathrm{a}}$ & $2.52^{\mathrm{a}}$ & $3.14^{\mathrm{a}}$ & $3.90^{\mathrm{b}}$ & $3.44^{\mathrm{a}}$ & $4.39^{\mathrm{b}}$ & $2.73^{\mathrm{a}}$ & $4.37^{\mathrm{a}}$ & $5.03^{\mathrm{a}}$ & 3.66 \\
\hline CK & $3.79^{\mathrm{b}}$ & $1.46^{\mathrm{b}}$ & $2.91^{\mathrm{a}}$ & $3.52^{\mathrm{a}}$ & $3.64^{\mathrm{a}}$ & $4.12^{\mathrm{a}}$ & $1.91^{\mathrm{b}}$ & $3.50^{\mathrm{b}}$ & $3.96^{\mathrm{b}}$ & 3.20 \\
\hline
\end{tabular}

Means within a row in the same year followed by the same letters are not significantly different at $P<0.05$.

Nine years mean yield of controlled traffic was $12.6 \%$ higher than that of CK, and in five out of nine years, controlled traffic treatments showed significant advantages in winter wheat yield, compared with CK $(P<0.05)$. Within controlled traffic treatments, NTCN and STCN showed similar performance on yield. Furthermore, the soil water conservation benefits of controlled traffic system reduced the effects of precipitation amount and timeliness on yield. The mean yield and standard deviation for NTCN, STCN and CK was $3.55 \pm 0.54$ ton $\cdot \mathrm{ha}^{-1}, 3.66 \pm 0.65$ ton $\cdot \mathrm{ha}^{-1}$ and $3.20 \pm 0.97 \mathrm{ton} \cdot \mathrm{ha}^{-1}$, which indicated that controlled traffic was less affected by precipitation variations, thus to enhance the stability of crop production.

Consistent with yield, nine years mean WUE of controlled traffic treatments was 5.2\% higher than that of $\mathrm{CK}$, and in four years, controlled traffic treatments showed significant advantages in winter wheat yield compared with CK $(P<0.05)$ (Table 5). Within controlled traffic treatments, NTCN and STCN showed no significant difference $(P<0.05)$, as a result of similar ET and yield effects. These data showed that, controlled traffic improved WUE in rain-fed farming in Loess Plateau, as a result of improved soil structure, increased soil water available (Table 3) and reduced potential evaporation.

Winter wheat water use efficiency from 1999 to 2007 [ton/hm²]

Table 5

\begin{tabular}{|c|c|c|c|c|c|c|c|c|c|c|}
\hline & $\mathbf{1 9 9 9}$ & $\mathbf{2 0 0 0}$ & $\mathbf{2 0 0 1}$ & $\mathbf{2 0 0 2}$ & $\mathbf{2 0 0 3}$ & $\mathbf{2 0 0 4}$ & $\mathbf{2 0 0 5}$ & $\mathbf{2 0 0 6}$ & $\mathbf{2 0 0 7}$ & Mean \\
\hline NTCN & $17.9^{\mathrm{a}}$ & $14.3^{\mathrm{a}}$ & $11.0^{\mathrm{a}}$ & $15.4^{\mathrm{a}}$ & $11.6^{\mathrm{a}}$ & $10.3^{\mathrm{a}}$ & $12.8^{\mathrm{a}}$ & $11.8^{\mathrm{a}}$ & $14.8^{\mathrm{a}}$ & 13.3 \\
\hline STCN & $18.4^{\mathrm{a}}$ & $14.4^{\mathrm{a}}$ & $11.5^{\mathrm{a}}$ & $16.3^{\mathrm{a}}$ & $10.8^{\mathrm{a}}$ & $11.1^{\mathrm{a}}$ & $14.0^{\mathrm{b}}$ & $12.2^{\mathrm{a}}$ & $15.1^{\mathrm{a}}$ & 13.8 \\
\hline CK & $17.6^{\mathrm{a}}$ & $12.1^{\mathrm{b}}$ & $10.6^{\mathrm{a}}$ & $14.2^{\mathrm{b}}$ & $13.2^{\mathrm{b}}$ & $10.9^{\mathrm{a}}$ & $11.1^{\mathrm{c}}$ & $11.4^{\mathrm{a}}$ & $14.7^{\mathrm{a}}$ & 12.9 \\
\hline
\end{tabular}

Means within a row in the same year followed by the same letters are not significantly different at $P<0.05$. 
The results of winter wheat yield indicated that, in dry land farming of Loess Plateau, even $20 \%$ of field was occupied by wheel track, controlled traffic still can increase crop yield, thus secure the stability of food production, compared with conventional tillage. Controlled traffic had higher capacity for water conservation during fallow and more stable soil available water at planting time than conventional tillage [26]. As wheat yield was linearly related to soil water stored at planting and this positive relationship was more significant than the relationship to seasonal water use, the extra soil water stored (Table 3) can enhance crop productivity. The positive effects on crop yield of controlled traffic found in this study were consistent with the previous experimental results demonstrated by Chen et al [6] and Bai et al [17].

\section{Conclusion}

Traffic and tillage differently affected water conservation, water use efficiency and yield. Long-term controlled traffic practice in Loess Plateau significantly improved soil structure, increased soil water infiltration, thus increased water conservation during fallow period, therefore improving available soil water in the $0-100 \mathrm{~cm}$ soil depth, and reduced the yearly variation. Consequently, winter wheat yield and water use efficiency for controlled traffic treatments were significantly higher and more stable than that for conventional tillage. Within controlled traffic system, controlled traffic combined with no-tillage and straw cover (NTCN) has higher performance on conserving water, improving yield and water use efficiency. It is a valuable system for soil and water conservation for the sustainable development of agriculture in dryland China.

These results demonstrate that controlled traffic system can provide a significant improvement over the current farming system on the semiarid Loess Plateau. More research on the relationships between controlled traffic, soil structure, runoff and erosion reduction, and productivity is required to fully understand the benefits of controlled traffic system throughout the drylands of northern China and promote its application.

\section{Acknowledgements}

This work was supported by the Chinese National Science Funding (51175499), Shanghai Education Committee Funding (13YZ109), and the 12nd Five-year Support Program in Shanghai University of Engineering Science (2012-09-nhky). Thanks for the help from Australian Centre for International Agricultural Research (ACIAR), and Shanxi Provincial Government and Conservation tillage Research Center, MOA.

\section{References}

[1] Xie ZK,Wang YJ, Li FM. Effect of plastic mulching on soil water use and spring wheat yield in arid region of northwest China. Agricult Water Manage. 2005;75:71-83. DOI: 10.1016/j.agwat.2004.12.014.

[2] Shangguan ZP, Shao MA, Lei TW, Fan TL. Runoff water management technologies for dryland agriculture on the Loess Plateau of China. Int J Sustainable Dev World Eco. 2002;1(9):341-350. DOI: 10.1080/13504500209470129.

[3] Wang QJ, Chen H, Li HW, Li WY, Wang XY, McHugh AD, He J, et al. Controlled traffic farming with no tillage for improved fallow water storage and crop yield on the Chinese Loess Plateau. Soil Tillage Res. 2009;104(1):192-197. DOI: 10.1016/j.still.2008.10.012.

[4] Tullberg JN, Yule DF, McGarry AD. Controlled traffic farming from research to adoption in Australia. Soil Tillage Res. 2007;97:272-281. DOI: 10.1016/j.still.2007.09.007. 
[5] Kang S, Zhang L, Song XY, Zhang SH, Liu XZ, Liang YL, Zheng SQ. Runoff and sediment loss responses to rainfall and land use in two agricultural catchments on the Loess Plateau. Hydrol Process. 2001;15:977-988. DOI: 10.1002/hyp.191.

[6] Chen H, Bai YH, Wang QJ, Chen F, Li HW, Tullberg JN, Murray JR, et al. Traffic and tillage effects on wheat production on the Loess Plateau of China: 1. Crop yield and SOM. Aust J Soil Res. 2008;46:645-651. DOI: $10.1071 /$ SR07106.

[7] Huang MB, Shao MA, Zhang L. Water use efficiency and sustainability of different long-term crop rotation systems in the Loess Plateau of China. Soil Tillage Res. 2003;72:95-104. DOI: 10.1016/S0167-1987(03)00065-5.

[8] Wang XB, Cai DX, Hoogmoed WB, Oenema O, Perdok UD. Developments in conservation tillage in rainfed regions of North China. Soil Tillage Res. 2007;93:239-250. DOI: 10.1016/j.still.2006.05.005.

[9] Tullberg J. Tillage, traffic and sustainability - A challenge for ISTRO. Soil Tillage Res. 2010;111:26-32. DOI: $10.1016 /$ j.still.2010.08.008.

[10] Gicheru P, Gachene C, Mbuvi J, Mare E. Effects of soil management practices and tillage systems on surface soil water conservation and crust formation on a sandy loam in semi-arid Kenya. Soil Tillage Res. 2004;75:173-184. DOI: 10.1016/S0167-1987(03)00161-2.

[11] Hamza MA, Anderson WK. Soil compaction in cropping systems: A review of the nature, causes and possible solutions. Soil Tillage Res. 2005;82:121-145. DOI: 10.1016/j.still.2004.08.009.

[12] McHugh AD, Tullberg JN, Freebairn DM. Controlled traffic farming restores soil structure. Soil Tillage Res. 2009;104:164-172. DOI: 10.1016/j.still.2008.10.010.

[13] Radford BJ, Bridge BJ, Davis RJ, McGarry D, Pillai UP, Rickman JF, et al. Changes in the properties of a Vertisol and responses of wheat after compaction with harvester traffic. Soil Tillage Res. 2000;54:155-170. DOI: 10.1016/S0167-1987(00)00091-X

[14] Li YX, Tullberg JN, Freebairn DM. Traffic and residue cover effects on infiltration. Aust J. Soil Res. 2001;39:239-247. DOI: 10.1071/SR00017.

[15] Wang XY, Gao HW, Tullberg JN, Li HW, Kuhn N, McHugh AD, et al. Traffic and tillage effects on runoff and soil loss on the Loess Plateau of northern China. Aust J Soil Res. 2008;46:667-675. DOI: 10.1071/SR08063.

[16] Chen H, Yang YL, Chen LH. Effect of wheel traffic on soil water infiltration. Advan Mater Res. 2010;113-114:335-338. DOI: 10.4028/www.scientific.net/AMR.113-116.335.

[17] Bai YH, He J, Li HW, Wang QJ, Chen H, Kuhn NJ, et al. Soil structure and crop performance after 10 years of controlled traffic and traditional tillage cropping in the dryland Loess Plateau in China. Soil Sci. 2009;174(2):113-119. DOI: 10.1097/SS.0b013e3181981ddc.

[18] He J, Wang QJ, Li HW, Liu LJ, Gao HW. Effect of alternative tillage and residue cover on yield and water use efficiency in annual double cropping system in North China Plain. Soil Tillage Res. 2009;104(1):198-205. DOI:10.1016/j.still.2008.08.015.

[19] Berzsenyi Z, Gyorffy B, Lap DQ. Effect of crop rotation and fertilization on maize and wheat yields and yield stability in a long-term experiment. Eur J Agron. 2000;13:225-244. DOI: 10.1016/S1161-0301(00)00076-9.

[20] Kukal SS, Aggarwal GC. Puddling depth and intensity effects in rice-wheat system on a sandy loam soil. I. Development of subsurface compaction. Soil Tillage Res. 2003;72:1-8. DOI: 10.1016/S0167-1987(03)00093-X.

[21] Bai YH, Chen F, Li HW, Chen H, He J, Wang QJ, et al. Traffic and tillage effects in wheat production on the Loess Plateau of China: 2. Soil physical properties. Aust J Soil Res. 2008;(46):652-658. DOI: 10.1071/SR07193.

[22] Li YX, Tullberg JN, Freebairn DM. Wheel traffic and tillage effects on runoff and crop yield. Soil and Tillage Res. 2007;97:282-292. DOI: 10.1016/j.still.2005.10.001.

[23] Huang YL, Chen LD, Fu BJ, Huang ZL, Gong J. The wheat yields and water-use efficiency in the Loess Plateau: straw mulch and irrigation effects. Agricult Water Manage. 2005;72:209-222. DOI: 10.1016/j.agwat.2004.09.012.

[24] Li HW, Gao HW, Wu HD, Li WY, Wang XY, He J. Effects of 15 years of conservation tillage on soil structure and productivity of wheat cultivation in northern China. Aust J Soil Res. 2007;45:344-350. DOI: 10.1071/SR07003.

[25] Li YX, Tullberg JN, Freebairn DM, Li HW. Functional relationships between soil water infiltration and wheeling and rainfall energy. Soil Tillage Res. 2009;104:156-163. DOI: 10.1016/j.still.2008.10.023.

[26] Sadras VO, Garry JO, David KR. Crop responses to compacted soil: capture and efficiency in the use of water and radiation. Field Crops Res. 2005;91(14):131-148. DOI: 10.1016/j.fcr.2004.06.011. 


\title{
WPEYW SPOSOBU UPRAWY ROLI NA OCHRONE WODY GLEBOWEJ I PLONY PSZENICY OZIMEJ NA WYŻYNIE LESSOWEJ, CHINY
}

\begin{abstract}
Abstrakt: Na Wyżynie Lessowej w północnych Chinach woda deszczowa jest czynnikiem ograniczającym wydajność plonów zbóż. W tym regionie tradycyjna orka połączona z usuwaniem słomy spowodowała osłabienie struktury gleby oraz redukcję zasobów wody, co w rezultacie doprowadziło do zmniejszenia plonów. Kontrolowany ruch maszyn, w połączeniu z rezygnacją z orki i wykorzystaniem słomianej osłony powierzchni gleby, zostały zaproponowane w celu poprawy ochrony gleby i zwiększenia plonów. W latach 1999-2007 na suchych obszarach Wyżyny Lessowej przeprowadzono doświadczenia polowe z wykorzystaniem pszenicy ozimej, których celem było zbadanie wpływu ruchu i sposobu uprawy gleby na ochronę zasobów wodnych i plony uprawianych roślin. Doświadczenie polowe przeprowadzono na polach uprawnych z kontrolowanym ruchem, przygotowanych na dwa sposoby. Jedno z pól było niezaorane, jego powierzchnia nie była utwardzana, pozostawiono nienaruszone resztki pokrycia $(\mathrm{NTCN})$. Drugie pole było podobnie przygotowane, ale w odróżnieniu od pierwszego zastosowano płytką orkę (STNC). Otrzymane wyniki porównano do tych, które uzyskano z pól przygotowanych w sposób konwencjonalny (CK). Wyniki wykazały, że kontrola i ograniczenie ruchu zmniejszyły zbijanie się górnych warstw gleby, zwiększając przenikanie wody w głąb niej. Korzystnym skutkiem przenikania wody do gleby była lepsza jej ochrona $(16,1 \%) \mathrm{w}$ warstwie $0-100 \mathrm{~cm}$ w kolejnych okresach i większa dostępność wody w glebie w czasie wysiewu (16,5\%), przy mniejszej rocznej zmienności. W wyniku wykorzystania systemu sterowania ruchem plony pszenicy wzrosły o $12,6 \%$, a efektywności wykorzystania wody poprawiła się o 5,2\% w porównaniu z uprawą tradycyjną. Najlepszą ogólną wydajność zaobserwowano na polu NTCN. Podsumowując, można stwierdzić, że kontrola ruchu, brak orki i ochrona powierzchni za pomocą słomy mają znaczny wpływ na ochronę zasobów wody w glebie, poprawiając wydajność produkcji i efektywność wykorzystania wody. Opisany system ochrony gleby i wody jest istotny dla zrównoważonego rozwoju rolnictwa na suchych obszarach Chin.
\end{abstract}

Słowa kluczowe: ruch kontrolowany, pszenica ozima, ochrona wód, plon pszenicy, Wyżyna Lessowa 